\begin{tabular}{|c|c|c|}
\hline$x$ & 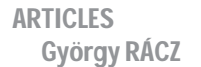 & 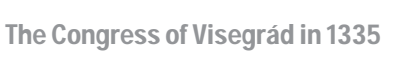 \\
\hline
\end{tabular}

\title{
The Congress of Visegrád in 1335 György RÁCZ
}

\author{
Magyar Nemzeti Leveltár \\ National Archives of Hungary \\ Bécsi Kapu tér 2-4, 1014 Budapest, Hungary \\ racz.gyorgy@mnl.gov.hu
}

The Congress of Visegrád in 1335 was by far the biggest diplomatic event that took place in Central Europe in the first half of the $14^{\text {th }}$ century. It must have been organized according to the choreography known for centuries, and since we hardly know anything about the details of the earlier congresses, it gives us information about the roots of the large international and political congresses of the Modern Age. The initiator and the choice of the location are extremely important; these matters are usually strongly related and can seldom be separated. It is notable how the negotiating parties changed documents at the end of the meetings and gave each other gifts, and the participating political dynasties consolidated their relationships through marital connections. It has also been observed that the negotiating parties arrived with a great retinue, and providing hospitality and entertainment was the task of the host.

\section{The sources}

The source characteristics can be considered poor compared to modern sources and as such, they do not help reveal the details. Over the course of many years of diplomatic procedures that involved a number of countries, a great many official documents have been produced, and usually exchanged - temporarily or permanently - by the negotiating parties. However, only a part of the original written sources has survived. For instance, the copies in Hungarian possession vanished completely during the destruction of the royal archives under Turkish rule. Many charters have been preserved by the royal Czech archives, while others can be found in Wroclaw - owing to its involvement in the process. The rest of the charters survived in the archives of the Order of Teutonic Knights in Königsberg, later to be transported, first to the Staatliches Archivlagerbe in Göttingen and then to the Preussicher Kulturbesitz collection of the Geheimes Staatsarchiv in Berlin. ${ }^{1}$ Contemporary chroniclers soon realized the significance of this event and reported on it in several documents in all the countries involved. In Bohemia, Charles of Luxembourg, Margrave of Moravia in his autobiographies and in Poland and Hungary, the $15^{\text {th }}$ century chroniclers - Jan Długosz and János Thuróczy - in their chronicles, told us the story. But contemporary Czech historiography, represented by the Chronicle of Francis of Prague, compiled in the first half of the $14^{\text {th }}$ century, is also very important. These narrative sources are part of the reception of the congress. We'll return to them later.

1 Six documents are published in the Latin language, with English, Czech, Hungarian, Polish and Slovak translations: Visegrád 1335, RÁCZ, György (ed.), Bratislava 2009. The original signatures and editions of the charters discussed here can be found in: RÁCZ, György: The Congress of Visegrád in 1335: Diplomacy and Representation, in: Hungarian Historical Review, 2, 2013, 2, 261-287. 


\section{Why was Visegrád chosen as a location?}

The scenic little town of Visegrád is located in the largest bend of the river Danube. Historical sources unanimously testify that here, in the autumn of 1335 , the leaders of Central European kingdoms held an international conference, a so-called meeting of the kings, in order to resolve international disputes. The meeting was held in the court of Hungarian King Charles I of Anjou, the actual initiator of the meeting. The upper castle on the hilltop was built during the reign of King Béla IV to provide a line of defense in the event of a new invasion. The strategic significance of this location led to the extension of the upper castle with a massive keep by the Danube, as well as the construction of a fortified wall that connected the upper and lower castles, turning the hillside into a formidable system of fortification.

Interestingly enough, the Slavic origin of the name "Visegrád", (meaning "high castle") does not refer to what is now the upper castle but to an older one built on a hill farther north. What was once a Roman fort later became a count's (ispán's) castle, which the local Slavs called "high castle", a name retained by the Hungarians even after the building's dilapidation. Populated by German settlers, the village at the foot of the hill had rapidly become a town in the second half of the $13^{\text {th }}$ century, shortly after Hungarian King Charles I of Anjou had relocated his seat from Temesvár to Visegrád in 1323 and defeated his oligarchic opposition. It was here that the central court and the administration were established. The harmony of landscape and architecture that evolved at the foot of the hill inspired Charles I of Anjou to envision what would become one of Central Europe's most significant royal seats in the $14^{\text {th }}$ century. The excavation of the buildings of the royal court destroyed under Turkish rule has been under way since 1934. Archaeologists have uncovered the foundations of the palace built by the Anjous, where an assassination was attempted against Charles I in 1330. By 1335, the castle and the town were capable of accommodating Bohemian King John of Luxembourg, his son and heir Charles, the Count of Moravia, Casimir III (the Great), Prince Rudolph of Saxony and Boleslaw III Duke of Silesia, representatives of the Order of Teutonic Knights as well as their entourage for over an entire month. ${ }^{2}$

\section{Why were these negotiations necessary and what were the main points?}

In order to understand the reasons that had led to the royal meeting, one needs to study the circumstances of the respective countries at the beginning of the $14^{\text {th }}$ century. Although the spread of the Black Plague and other epidemics in this time period marked the closure of the Middle Ages in Western Europe, the culture of chivalry was at that time still in bloom. The $14^{\text {th }}$ century history of the three Central European kingdoms, Bohemia, Poland,

2 The most recent literature on the town, the castle and the palace include: LÁSZLÓ, Iván: A visegrádi vár története a kezdetektől 1685-ig, Visegrád 2004, especially 24, 37; BOZÓKI, Lajos: A fellegvár leírása és építéstörténete, in: A visegrádi fellegvár, BUZÁS, Gergely (ed.), Visegrád 2004, 7-25; MÉSZÁROS, Orsolya: A késő középkori Visegrád város története és helyrajza, Visegrád 2009, 19-27; BUZÁS, Gergely: A visegrádi királyi palota története, in: A visegrádi királyi palota, BUZÁS, Gergely - OROSZ, Krisztina (eds.), Budapest 2010, 11-17. 
and Hungary, features a time of progress and development reflected in similar ways in each country. At the beginning of the century, all three neighboring kingdoms had been experiencing frictions and social unrest. By the second half of the century, the three leaders managed to resolve inner conflicts and build up strong countries. In Bohemia and Hungary, the old dynasties had died out almost simultaneously at the beginning of the 1300s, while in Poland, Lokietek - who was directly descended from the last Polish king of the Piast dynasty - ascended to the throne. The demanding tasks that all three countries were about to face informed their relationship to one another. Wladislaw I Lokietek, Duke of Krakow (1305-1320), succeeded in unifying the fractured Polish territories and made himself king upon the approval of the Pope in 1320, thus re-making the Kingdom of Poland (Lokietek ruled from 1320-1333). In Hungary, once the lineage of the Árpád dynasty ended in 1301, Charles I of Anjou (1301-1342) came to the throne and, like Lokietek, commenced his reign with dedication and the gift of leadership. The Polish and the Hungarian rulers had been supporting each other in their battles against the oligarchs in their own territories, and this alliance would become a foundational pillar of Central European politics throughout the $14^{\text {th }}$ century. ${ }^{3}$

With the end of the Bohemian Premyslid dynasty in 1306, the adversary of the Anjous, John of Luxembourg (1310-1346), ascended to the throne of Bohemia, which brought stability in Bohemian-Hungarian relations as well. One indication of this is that Charles I of Anjou, having suffered the untimely loss of his first two wives, married Beatrix of Luxembourg, sister of the Bohemian king in 1317. The death of Beatrix in 1319, however, put an early end to this marriage. Because John did not have any more sisters, Charles resorted to asking his other neighbor, the Polish king, for a fiancé. His marriage with Elizabeth, daughter of the newly crowned Wladislaw I Lokietek in 1320 forged a strong alliance between Hungary and Poland. At the same time, King John provided further support to Charles's campaign against Máté Csák, his major adversary - a favor Charles did not let go unreturned. With the subsequent corruption of Hungarian-Austrian relations, the ties between the two kings strengthened, owing to the long-standing acrimony between the Luxembourgs and the Habsburgs.

Charles's good relations with both countries were eclipsed, however, by the animosity between the Bohemians and the Poles. One of the causes of this conflict lies in the Luxembourgs' claim to the Polish throne, on grounds of the same claim of the earlier Premyslid kings. According to the rules of contemporary international relations, such a claim was legally justifiable and entailed the entire heritage of Wenceslaus II (1305-1306). The realization of this goal, however, was hindered by the unsuccessful campaign of the Bohemian king on the one hand, and the diplomatic policies of the Anjous, supportive of Lokietek, on the other. As a result, John of Luxembourg reduced his claim to Greater

3 On the contemporary situation of the three countries and their political history, I have used the following basic works, to which I make no reference henceforth: KNOLL, Paul W.: The Rise of the Polish Monarchy: Piast Poland in East Central Europe, 1320-1370, Chicago and London 1972; SZCZUR, Stanisław: Historia Polski: Średniowiecze, Krakow 2002; ENGEL, Pál: The Realm of St Stephen. A History of Medieval Hungary, 895-1526, London-New York 2001, 130-34, 136-37. On the details of Hungarian domestic policies, see ENGEL, Pál: Az ország újraegyesítése. I. Károly küzdelmei az oligarchák ellen (1310-1323), in: Századok, 122, 1988, 1-2, 89-146. A modern, balanced survey on the reign of Charles I is CSUKOVITS, Enikő: Az Anjouk Magyarországon I. I. Károly és uralkodása (1301-1342), Budapest 2012. 
Poland and yielded Pomerania to the Teutonic Order. The Piasts had intended to lay claims on Silesia, a one-time Polish territory, but by the beginning of the $14^{\text {th }}$ century, the Silesian rulers were already under the over-lordship of the Luxembourgs.

After the death of Wladislaw I Lokietek in 1333, his son Casimir III ascended to the throne, which created a new dynamic in the relations of the three countries. Once in power, Casimir launched himself into the task of sorting out matters left to him by his father. Poland was not only burdened by the feud with the Luxembourgs but by territorial disputes with the Teutonic Order as well. With the new king on the Polish throne, John of Luxembourg also took interest in ameliorating Bohemian-Polish relations, for he was in search of an ally against his long-time enemies, the Austrians and the Holy Roman Emperor Ludwig of Bavaria, with whom he had disputes over the heritage of Henry, Duke of Carinthia. In 1334, to settle the dispute over Polish territories, the parties involved chose arbiters: the Polish king appointed Charles of Anjou, while the Teutonic Order appointed John of Luxemburg. This move served as a platform for the subsequent peace process. The Hungarian king - who, after the death of Lokietek, became ruler of the region - accepted the task with great zeal and mediated between the old Bohemian king and the young Polish ruler. Chief among his motives was his long-term goal to lay claim to the Polish throne for the Anjou dynasty. With Hungary as mediator, the conference at Visegrád thus marked the closure of a two-year process of diplomatic negotiations between Bohemia and Poland on the one hand, and Poland and the Teutonic Order on the other. The mechanism of diplomatic preparations seems to have been engineered in Visegrád, which involved the constant coming and going of deputies to maintain contact and secure the flow of information. ${ }^{4}$

\section{Previous direct history}

As a first step, Casimir III signed a one-year ceasefire with Charles, Moravian Margrave and son of Bohemian King John, at Sandomir, 28 May 1335. In the treaty, he included Hungarian King Charles I of Anjou, along with two Polish dukes as bail to seal the peace treaty with their charters. ${ }^{5}$ Afterwards, on 24 August, John and Casimir's deputies met in the Hungarian town of Trencin (now part of Slovakia). Casimir authorized his deputies to follow the advice of the representatives of the Hungarian king throughout the peace process. The deputies also had the right to take financial responsibilities on behalf of the king up to 30,000 silver Marks. The Polish politicians were well aware that reimbursement of the financially unstable Bohemian king would be the key to the solution. After all, with the exception of the financial aspect, the points of the peace treaty, which constituted the Bohemian king's claims on the Kingdom of Poland, had already been clarified. Consequently, King John, along with his

415 May 1334, in: Codex diplomaticus Prussicus. Urkunden-Sammlung zur ältern Geschichte Preussens aus dem Königl. Geheimen Archiv zu Königsberg nebst regesten (hereinafter referred only as CDP), Vol 2, VOIGT, Johannes (ed.), Königsberg 1842, 194-95; see also: Das virtuelle Preußische Urkundenbuch. Regesten und Texte zur Geschichte Preußens und des Deutschen Ordens (hereinafter referred only as VPU), no. PrUB 2.842 (online http://www1.uni-hamburg.de/Landesforschung/pub/orden1334.html, accessed 3 September 2013). On Polish diplomacy, see also SZCZUR, Stanislaw: Dyplomaci Kazimierza Wielkiego w Awinionie, in: Nasza Przeszlosc, vol. 66, 1986, 43-106.

5 Archiv koruny české, vol. 2. Katalog listin z let 1158-1346, KOSS, Rudolf (ed.), Praha 1928, 140-41 (no. 176) with the data of previous editions. 


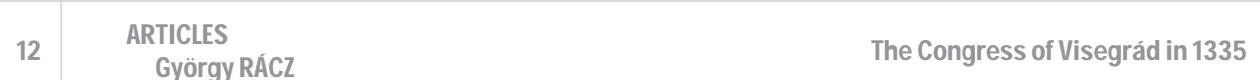

son, waived his rights concerning Poland, while the Polish king gave up the feudal tenures of Bohemian-governed Silesia and Masovia. The agreement was documented in a charter issued by the representatives of Casimir and sealed by their own seals, upon the promissory note that the Polish king would confirm it as well. ${ }^{6}$ With that, the Bohemian delegation went to the Hungarian royal court in Visegrád, where the Bohemian-Hungarian agreement was soon signed. The copy, dated 3 September, issued and sealed by the Hungarian king, has survived in the royal Czech archives. This agreement was especially important to the Luxembourgs because it would help them break the shackles of political isolation. ${ }^{7}$

Now the time was ripe for the commencement of the negotiations between the arbiters and for the meeting of the three kings. At the beginning of November 1335, the 47 yearold Hungarian King Charles I of Anjou invited and hosted his brother-in-law and ally, the 25 year-old Polish King Casimir III, the 39 year-old Bohemian King John of Luxembourg, along with his 19 year-old son Charles, the Margrave of Moravia (later to be Emperor Charles IV), and the many Polish, Silesian, and German principals as part of their delegations, as well as the representatives of the Teutonic Order, for over three to four weeks.

\section{What kind of information do we have about the details of the congress?}

Charles of Luxembourg, Margrave of Moravia and later to be emperor, offers an account of the congress in his autobiographies, which constitutes a contemporary report on the event, given that he attended it in person. No wonder he does not go into detail about the formalities of hospitality, nor does he provide insight into the dynamics of the talks; yet it comes rather as a surprise that he emphasizes the Bohemian-Polish-Hungarian alliance only, without discussing the arbitration process. In his work, he mentions that his father was already in Visegrád when he arrived; he then goes on to explicate the above-mentioned familiar relationships among the rulers, and finally describes the roots of the BohemianPolish dispute. ${ }^{8}$ Luckily, the $15^{\text {th }}$ century Polish chronicler Jan Długosz highlights this other aspect of the congress in his account: the actual reason the kings gathered together in Visegrád was to settle the dispute over those Polish territories seized by the Teutonic Knights. Not only did Długosz capture the essence of the event, he also provided the text of the charter for peace as well. He could provide no information about details of the meeting. ${ }^{9}$

The text of a $14^{\text {th }}$ century chronicle has survived in the work of the $15^{\text {th }}$ century Hungarian chronicler János Thuróczy, which gives a presumably contemporary account of the formal details of the meeting in 1335. Unlike Długosz's account, this document focuses primarily

6 Lehns- und Besitzurkunden Schlesiens und seiner einzelnen Fürstenthümer im Mittelalter. 1-2. Theil, GRÜNHAGEN, Colmar - MARKGRAF, Hermann (eds.), Leipzig 1881, vol. 1., no. 1.

7 Codex Diplomaticus Silesiae. Regesten zur Schlesischen Geschichte 1334-1337 (hereinafter referred only as CDS), vol. 29, WUTKE, Konrad (ed.), Breslau 1923, 57 (no. 5499); The latest edition is: Visegrád 1335, 83-85.

8 Karoli IV Imperatoris Romanorum Vita ab eo ipso conscripta et Hystoria Nova de Sancto Wenceslao Martyre. Autobiography of Emperor Charles IV and his Legend of St. Wenceslas, NAGY, Balázs - SCHAER, Frank (eds.), Budapest-New York 2001, 80-83.

9 DLUGOSSI, loannis: Annales seu cronicae incliti regni Poloniae. Liber nonus, TURKOWSKA, D. (ed.), Warsaw 1978; DŁUGOSZ, Jan: The Annales of Jan Długosz, MICHAEL, Maurice (ed.), Charlton Mill 1997, $285-86$. 
on formalities but such a description is just as valuable for us as political data. Let it be quoted here word for word:

"In the $1335^{\text {th }}$ year of the Lord, around the festivities of Saint Martin, Bohemian King John, his son Charles, and the king of the Poles came to the castle of Visegrád, to the court of King Charles, to seal their alliance with a peace treaty for all time. And so it happened. Out of the generosity of the Hungarian king, 2,500 loaves of bread were provided for the lunch of the Bohemian king, as well as a good share of the royal meals, all in abundance, while the horses' day share of fodder was 25 "garleta". For the lunch of the Polish king 1,500 loaves of bread and other foods, as well as 180 barrels of wine were provided. The king of Hungary presented the Bohemian king with various sorts of jewelry: 50 silver jars, two quivers, two belts, a magnificent chess board, two invaluable saddles, a knife with a belt that are worth 200 silver Marks, and an elaborate pearl-oyster. Because the king of Poland was to pay homage to the king of Bohemia, and because Charles, King of Hungary, made the sister of the Polish king his wife, Charles, King of Hungary gave him 500 Marks of the finest gold so as to save him from paying taxes to the Bohemian king. It has also been resolved that in the event of an enemy attack on any one of these countries, the others will help the one in trouble. And this has been sealed by an oath among one another." 10

In contemporary Czech historiography, represented by the Chronicle of Francis of Prague, compiled in the first half of the $14^{\text {th }}$ century, the attitude is illustrated by the very title of its relevant chapter: "How the King of Bohemia Alienated Poland". The author answered the question in the following way. The king of Bohemia, in the company of his firstborn, Charles, and several noblemen, went peacefully to Hungary and visited its king, Charles. There he spent three weeks, over the course of which they mutually preserved the fidelity and concord that existed between them, and confirmed them by oath, whereupon the king of Bohemia and his retinue returned to his kingdom, loaded with gifts. He took with him to Prague Casimir III, already king of Poland, to whom he had sold Poland for twenty thousand marks in the presence of the king of Hungary. Here the Polish king spent several days, seeing many honors lavished upon him, and then returned home, where he proclaimed the happy news of having obtained the right and title to the Kingdom of Poland. While still in Hungary, these three kings had sworn a mutual alliance against all princes (contra omnes principes). Part of this alliance was a promise that the daughter of the Polish king would be given in marriage to the brother-in-law of the king of Bohemia, namely the five-year-old son of Henry, duke of Bavaria, who was called John. ${ }^{11}$

The official documents released in Visegrád in the autumn of 1335 do little to nuance the descriptions of the chroniclers. Although the chronicles do have a kernel of truth, the event that they describe often took place in a different place, at a different time, in a different manner. In the above example, the chronicler falsely asserts that Poland, as a feudal subject,

10 THUROCZ, Johannes de: Chronica Hungarorum I. Textus, GALÁNTAI, Erzsébet - KRISTÓ, Gyula (eds.), Budapest 1985, 152-53.

11 Chronicon Francisci Pragensis/Kronika Františka Pražského, ZACHOVÁ, Jana (ed.), Praha 1997, 159-160. 
had paying commitments to Bohemia and that Charles offered the required amount to "ransom" his brother-in-law. On the basis of the documents pertinent to the conference per se, it is possible to draw a more realistic picture. We have seen that at the meeting in Trenčín the "ransom" to be paid to the Bohemian king had not yet been specified. At the Visegrád meeting in November, however, Casimir III, experiencing financial difficulties at the time, had no choice but to haggle over the amount to be paid. He finally agreed to pay 20,000 threescore Prague groschen (20,000 Bohemian silver Marks) to the Bohemian king in exchange for the latter renouncing his title of Polish king. King John, in turn, issued a charter of abdication deposited with the Hungarian king. Should Casimir III fail to produce the amount missing, the Hungarian king had the choice of giving the deposited charter back to the king of Bohemia or supplying the missing 6,000 Marks himself. ${ }^{12}$ As 6,000 silver Marks make 500 golden Marks, the above-quoted chronicle pertains to this aspect of the event; thus, the chronicler mistakenly identifies the Hungarian king's collateral statement with the payment itself. ${ }^{13}$

The actual celebration of the treaty of alliance took place on 19 November, name-day of Elizabeth Piast, wife of the host king. Many charters were dated for that day, as was the Bohemian-Polish peace treaty, ${ }^{14}$ one of the most important documents of the meeting. Another charter of the same date provided for the security of the road leading from Poland to Wroclaw and the demolition of the castle of Boleslauitz (Boleslawiec). ${ }^{15}$ Yet another was a marriage contract among the allied dynasties (a usual protocol on such occasions) aimed at protecting the newly forged Bohemian-Polish alliance. Due to the lack of younger sisters to marry, Casimir III offered his baby daughter Elizabeth to the 6-year-old grandson of the Bohemian king, the only child of Henry, Duke of Bavaria and Duchess Margaret of Luxembourg (John's daughter). Due to the untimely death of the boy in 1340, the marriage was not realized. ${ }^{16}$

The signing of the peace treaty took place on the same day as the verbal declaration of the arbitration. A thorough study of the historical sources demonstrates that this was the underlying reason for the meeting of the kings. The adversaries had been conscientiously preparing for the decisive event of the arbitration proceedings: On 21 September 1335, the Teutonic Order had the charters that vindicated their rights copied in the archives of

12 See the charter issued by King Casimir and his sureties, dated November 22, 1335. published editions: Codex diplomaticus et epistolaris Moraviae (hereinafter referred only as CDM), vol. VII/1, CHYTIL, Josef (ed.), Brno 1858, 69-70 (no. 89), dated November 12, following the previous editions.

13 The exact conversion/commutation of the monetary data was performed by Elemér Mályusz in his commentaries to the critical edition of the Thuróczy Chronicle: THUROCZ, Johannes de: Chronica Hungarorum II. Commentarii 2. Ab anno 1301 usque ad annum 1487, MÁLYUSZ, Elemér - KRISTÓ, Gyula (eds.), Budapest $1988,78-79$.

14 CDM, vol. VII/1, 71-72 (no. 91). Visegrád 1335, 105-06.

15 LUDEWIG, Johann Peter von: Reliqviae manuscriptorum omnis aevi, diplomatum ac monvmentorvm, ineditorvm adhvc, vol. V, Frankfurt 1723, 588-89. Following him, and each other: Regesta diplomatica nec non epistolaria Bohemiae et Moraviae (hereinafter referred only as RBM), vol. IV, EMLER, Josef (ed.), Praha 1892, 88-89 (no. 225); CDS, vol. 29, 62 (no. 5520).

16 LUDEWIG, 292-293 (1305-series date). CDM, vol. 1/VII., 70-71. (nr. 90.) based on previous releases; RBM, vol. IV, 86 (nr. 222) based on past expenditure; CDS, vol. 29, 61 (nr. 5519). 
Marienburg (Malbork), ${ }^{17}$ while the Polish king had already submitted a lawsuit against the Teutonic Knights to the pontifical court of law in the summer of $1335 .{ }^{18}$ In Visegrád, the arbitration process had already commenced in November with the investigation into the plenipotentiary powers of the representatives of the Teutonic Order. This procedure was inevitable because the Great Master of the Order was absent from the meeting. Once the authorization documents were approved, the presentation of the statements and charters of the two sides followed. We have no information on the charters presented by the Polish deputies, but the Teutonic Knights certainly had those from the archives at Marienburg in their hands, as well as a complete draft for the peace treaty that they had designed early on. ${ }^{19}$ The arbitration was first declared orally, definitely before 21 November, which is the date of the charter addressed by Wladislaw, Duke of Leczyca and Borzyn, to John of Luxembourg. Wladislaw cites the decree of the court of arbitration, which disposes of the territories of Dobrzyn, hitherto under the rule of the Teutonic Order, to revert to Casimir III the Great. He reasserts that he had ruled over these territories until the Teutonic Knights and John of Luxembourg seized the area following the war waged against Lokietek. ${ }^{20}$

After days of negotiations between the arbiters and the barons, the arbitration was drafted in a charter dated 26 November. It posits that Casimir III ruled over Kujawy and Dobrzyn, while the Teutonic Order received Pomerania. ${ }^{21}$ In his letter dated 3 December, the King of Bohemia informed the Master of the Teutonic Knights of the dispositions drawn up during the meeting and of the subsequent duties at hand. ${ }^{22}$ Although there is no indication as to where the letter was written, it is quite certain that it was not written in Visegrád. According to the dates mentioned in the charters, the kings convened around All Saints' Day, which designates 1 November as the starting date of the conference. In his letter dated 3 December, King John talks about a 3-week-long meeting; but the peace treaty between the Teutonic Order and Poland, which took place on 26 November in the presence of all invitees, indicates that the meeting lasted a bit longer. Casimir drafted another charter, addressed to the Teutonic Order and dated 26 May 1336, declaring acceptance of the arbitration. ${ }^{23}$

17 Preußisches Urkundenbuch (hereinafter referred only as PU), vol. III/1 (1335-1342), HEIN, Max (ed.), Königsberg 1944, nos. 11-16; VPU, 3.11-16.

18 CHLOPOCKA, Helena: Galhard de Carceribus i jego rola w sporze polsko-krzyżackim w XIV w., in: Europa - Słowiańszczyzna - Polska. Studia ku uczczeniu Profesora Kazimierza Tymienieckiego, BARDACH, Juliusz et al. (eds.), Poznań 1970, 135-45.

19 The articles of the peace treaty are known from a fifteenth-century copy: VPU, 3.27.

20 Judging by the place where it is kept now, it must have been the copy of John of Luxemburg. Published editions: PU, vol. III/1, no. 30; RBM, vol. III, no. 2060; CDS, vol. 29, 62. In the dating tricesimo tercio is an evident misspelling of tricesimo quinto.

21 Published editions: RBM, vol. IV, 89-90 (no. 228); PU, vol. III/1, 32; CDS, vol. 29, 63 (no. 5526).

22 Published editions: Visegrád 1335, 156; CDM, vol. 1/VII, 75 (no. 98); PU, vol. III/1, 33.

23 PU, vol. III/1, no. 64 


\begin{tabular}{|c|c|c|}
\hline 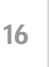 & 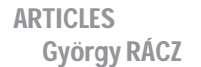 & 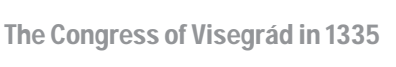 \\
\hline
\end{tabular}

\section{How many were there? How much did they drink and eat? The gifts}

Finally, as for the quantity of the meals and drinks, I tend to give credit to the chronicler. It is worth touching briefly upon the rather anomalous description of the conference that has come down to us as part of the Hungarian Thuróczy Chronicle, cited above. A closer examination of the text could probably take us nearer to establishing the size of the princely retinues that came to Visegrád, and thus provide relevant new information to both Czech and Polish historians. ${ }^{24}$ Thuróczy worked from the chronicle written in the $14^{\text {th }}$ century and adapted the information about the congress into his own chronicle in the fifteenth century. We have seen above that the 500 marks given by the king of Hungary exactly corresponded to the 6,000 silver marks of which King Charles I gave a warranty to King John on behalf of Casimir III the Great. Thus, the $14^{\text {th }}$-century Hungarian chronicler was apparently well informed about the financial aspects of the negotiations, which increases our confidence in the reliability of his other data. In my opinion, the chronicler drew on the accounts of the royal court, then still available, in which the expenses of the Hungarian king for 1335 were recorded.

For the lunch of the Czech king, 2,500 loaves of bread were distributed every day, along with an ample portion of the royal victuals. The fodder (pabulum) for the horses amounted to 25 garletas per day. The relevant figure of bread for the Polish king was 1,500 loaves, plus a share in the royal victuals, while 180 barrels (tunella) of wine were also on supply. If we take everything into account, a minimum of 5,000 Czech retainers and 3,000 Polish ones must have meant an onerous burden for the small town of Visegrád, especially in view of a stay there that extended for a whole month. Moreover, these persons and animals had to be not only fed but also accommodated, and the fodder of 25 cartloads a day stored somewhere on the territory of the town. If we take these numbers seriously, and we have no reason not to, as they mutually support each other, then we have to accept the fact that in 1335 the royal court at Visegrád, in the widest sense of the term, was able to host and provision an army of about 8,000 horsemen. ${ }^{25}$ This certainly indicates a fairly developed logistical ability on the part of the contemporary Hungarian royal court.

The list of those gifts offered to the king of Bohemia by his hosts, for instance, is more likely to have been taken from a contemporary notice or register than from the narrative of an eyewitness. It would be interesting to follow the traces, if any, of these gifts in later Czech tradition. The historians who have dealt with the topic provide the lists with variations. ${ }^{26}$

Finally, one more question must be asked. Was the enormous size of the royal retinues attending the summit an exception or the norm? The retinue of Sigismund of Luxemburg, which escorted him on his well-documented travels in Western Europe, numbered occasionally to 1,000 to 1,500 persons ${ }^{27}$ and that of the guests who gathered around him

24 See: RÁCZ, 2013.

25 According to Mátyás Szőke (personal communication), there are archeological finds in Visegrád that could be interpreted as grain-storage pits.

26 BONFINIS, Antonius de: Rerum Ungaricarum decades I-III, Vol. II, FÓGEL, I. - IVÁNYI, B. - JUHÁSZ, L. (eds.), Leipzig 1936, 213 (no. 2.9.360); DUBRAVIUS, loannes: Historiae regni Bohemiae, Francofurti 1687, 562.

27 CSUKOVITS, Enikő: Egy nagy utazás résztvevői (Zsigmond király római kísérete), in Tanulmányok Borsa Iván 
at Buda in 1412 also contained several thousand people. ${ }^{28}$ Prague and Krakow were too near to Visegrád for the kings of Poland and Bohemia to resist the temptation of taking a huge entourage with them. Was their enormous retinue a part of routine representation or did it amount to an extraordinary and purposeful display of strength? In order to answer this question, one has to remember on the one hand that from Bohemia two princes came, each with his own entourage. On the other hand, the kings of Bohemia and Poland engaged not only themselves but also their most powerful subjects in making the peace, and they could not terminate the negotiations without their knowledge and consent. We know that urban delegates were also present, for some of the documents have survived in the city archives of Wroclaw. Altogether, some forty individual partners can be shown to have participated in the negotiations, the Hungarian lords included. Naturally enough, each brought a retinue of his own, which, together, constituted a mass of some 10,000 people, organized into various hierarchical structures. In all probability, its constituent parts idled away their time by memorable amusements and hunts, excursions to Fehérvár and Buda, and, of course, by chivalric tournaments on the bank of the Danube, while the kings negotiated and made peace up in the Citadel or in the Solomon Tower.

Although the meeting received much attention from all sides, each party tends to highlight its own points of interest. As the event represented a turning point in $14^{\text {th }}$ century Polish international relations, it is not surprising that Polish historiography has addressed it in most detail, primarily focusing on Polish-Teutonic and Polish-Bohemian relations. Such aspects remained in the background in the writings of Hungarian chroniclers and, instead, the Visegrád meeting was widely understood as a crucible of economic alliances. This assumption was based on a decree issued by Charles I, in Visegrád, on 6 January 1336, which regulates routes of commerce and the customs tariff between Hungary and Bohemia. ${ }^{29}$ The text of the decree suggests that Charles I and King John had thoroughly discussed the issue beforehand - most certainly in November, in Visegrád. This move was most probably an attempt to evade Vienna's stable right and redirect trade between Germany and Hungary towards Brünn. Also, the cities in the territory of present-day Slovakia might have played a role in initiating this trade agreement. The meeting in Visegrád therefore did have an economic aspect; yet this should not be generalized into the main focus of the conference. ${ }^{30}$ Today, we can safely break with the narrowly nationalist approach of the medieval chroniclers and state that the prime cause of the Visegrád royal summit was to provide the occasion for the two arbiters, the kings of Hungary and Bohemia, to make their judgement in the dispute between Poland and the Teutonic Order.

tiszteletére, CSUKOVITS, Enikő (ed.), Budapest 1998, 11-36; BÁRÁNY, Attila: Zsigmond király 1416-os angliai kísérete, in: Aetas, 19, 2004, 3-4, 5-30; KOVÁCS, Péter E.: 'A Szent Koronára! Ez kedvemre telik'. Zsigmond császár Luccában, in: Századok, 141, 2007, 2, 355-56.

28 DRASKÓCZY, István: A tizenötödik század története, Budapest 2000, 150.

29 The newest edition: Visegrád 1335, 164-166.

30 Hungarian historiography now interprets differently the opening of the trading route of Brünn (Brno, Czech Republic), which had traditionally been explained in terms of an effort to get round the staple right of Vienna. SKORKA, Renáta: A bécsi lerakat Magyarországra vezető kiskapui, in: Történelmi Szemle, 54, 2012, 1, 1-16. 


\begin{tabular}{|c|c|c|}
\hline$c x$ & 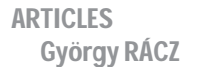 & 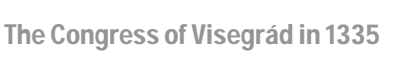 \\
\hline
\end{tabular}

\begin{abstract}
The article deals with the organisational aspects of the Congress of the Czech, Hungarian and Polish Kings in Visegrad in 1335. The introduction focuses on the sources of this research. The first substantive chapter deals with the political and logistical aspects for the choice of the location for the Congress and then with the main points of the negotiations. Significant part of the article is dedicated to the previous history of the Congress and to the organizational details. The readers can obtain a lot of information about the number of participants and about their social-cultural life during the Congress. Very interesting part of the article deals with the kind of official gifts and with the question of how much did the participants eat and drink. The article is a very important introduction to the every days life of the medieval Congresses and political summits of high ranks.
\end{abstract}

\title{
Keywords
}

congress, king, courts, negotiations, cultural life, Bohemia, Hungary, Poland

\section{References}

Archiv koruny české, vol. 2. Katalog listin z let 1158-1346, KOSS, Rudolf (ed.), Praha 1928. BONFINIS, Antonius de: Rerum Ungaricarum decades I-III, Vol. II, FÓGEL, I. - IVÁNYI, B. - JUHÁSZ, L. (eds.), Leipzig 1936.

Codex diplomaticus et epistolaris Moraviae, vol. VII/1, CHYTIL, Josef (ed.), Brno 1858.

Codex diplomaticus Prussicus. Urkunden-Sammlung zur ältern Geschichte Preussens aus dem Königl. Geheimen Archiv zu Königsberg nebst regesten, vol. 2, VOIGT, Johannes (ed.), Königsberg 1842.

Codex Diplomaticus Silesiae. Regesten zur Schlesischen Geschichte 1334-1337, vol. 29, WUTKE, Konrad (ed.), Breslau 1923.

Das virtuelle Preußische Urkundenbuch. Regesten und Texte zur Geschichte Preußens und des Deutschen Ordens, online http://www1.uni-hamburg.de/Landesforschung/ orden.html.

Lehns- und Besitzurkunden Schlesiens und seiner einzelnen Fürstenthümer im Mittelalter. 1-2. Theil, GRÜNHAGEN, Colmar - MARKGRAF, Hermann (eds.), Leipzig 1881.

LUDEWIG, Johann Peter von: Reliqviae manuscriptorum omnis aevi, diplomatum ac monvmentorvm, ineditorvm adhvc, vol. V, Frankfurt 1723.

Preußisches Urkundenbuch III/1 (1335-1342), HEIN, Max (ed.), Königsberg 1944.

Regesta diplomatica nec non epistolaria Bohemiae et Moraviae, vol. III, EMLER, Josef (ed.), Praha 1890.

Regesta diplomatica nec non epistolaria Bohemiae et Moraviae, vol. IV, EMLER, Josef (ed.), Praha 1892.

BÁRÁNY, Attila: Zsigmond király 1416-os angliai kísérete, in: Aetas, 19, 2004, 3-4, 5-30. BOZÓKI, Lajos: A fellegvár leírása és építéstörténete, in: A visegrádi fellegvár, BUZÁS, Gergely (ed.), Visegrád 2004, 7-25. 
BUZÁS, Gergely: A visegrádi királyi palota története, in: A visegrádi királyi palota, BUZÁS, Gergely - OROSZ, Krisztina (eds.), Budapest 2010, 11-17.

CSUKOVITS, Enikő: Egy nagy utazás résztvevői (Zsigmond király római kísérete), in: Tanulmányok Borsa Iván tiszteletére, CSUKOVITS, Enikő (ed.), Budapest 1998, 11-36.

CSUKOVITS, Enikő: Az Anjouk Magyarországon I. I. Károly és uralkodása (1301-1342), Budapest 2012.

DLUGOSSI, loannis: Annales seu cronicae incliti regni Poloniae. Liber nonus, TURKOWSKA, D. (ed.), Warsaw 1978.

DŁUGOSZ, Jan: The Annales of Jan Długosz, MICHAEL, Maurice (ed.), Charlton Mill 1997. DRASKÓCZY, István: A tizenötödik század története, Budapest 2000.

DUBRAVIUS, loannes: Historiae regni Bohemiae, Francofurti 1687.

ENGEL, Pál: Az ország újraegyesítése. I. Károly küzdelmei az oligarchák ellen (1310-1323), in: Századok, 122, 1988, 1-2, 89-146.

ENGEL, Pál: The Realm of St Stephen. A History of Medieval Hungary, 895-1526, LondonNew York 2001.

CHLOPOCKA, Helena: Galhard de Carceribus i jego rola w sporze polsko-krzyżackim w XIV w., in: Europa - Słowiańszczyzna - Polska. Studia ku uczczeniu Profesora Kazimierza Tymienieckiego, BARDACH, Juliusz et al. (eds.), Poznań 1970, 135-45.

Chronicon Francisci Pragensis/Kronika Františka Pražského, ZACHOVÁ, Jana (ed.), Praha 1997.

Karoli IV Imperatoris Romanorum Vita ab eo ipso conscripta et Hystoria Nova de Sancto Wenceslao Martyre. Autobiography of Emperor Charles IV and his Legend of St. Wenceslas, NAGY, Balázs - SCHAER, Frank (eds.), Budapest-New York 2001.

KNOLL, Paul W.: The Rise of the Polish Monarchy: Piast Poland in East Central Europe, 1320-1370, Chicago and London 1972.

KOVÁCS, Péter E.: 'A Szent Koronára! Ez kedvemre telik'. Zsigmond császár Luccában, in: Századok, 141, 2007, 2, 353-364.

LÁSZLÓ, Iván: A visegrádi vár története a kezdetektöl 1685-ig, Visegrád 2004.

MÉSZÁROS, Orsolya: A késő középkori Visegrád város története és helyrajza, Visegrád 2009, 19-27.

RÁCZ, György: The Congress of Visegrád in 1335: Diplomacy and Representation, in: Hungarian Historical Review, 2, 2013, 2, 261-287.

SKORKA, Renáta: A bécsi lerakat Magyarországra vezető kiskapui, in: Történelmi Szemle, $54,2012,1,1-16$.

SZCZUR, Stanislaw: Dyplomaci Kazimierza Wielkiego w Awinionie, in: Nasza Przeszlosc, vol. 66, 1986, 43-106.

SZCZUR, Stanisław: Historia Polski: Średniowiecze, Krakow 2002.

Visegrád 1335, RÁCZ, György (ed.), Bratislava 2009.

THUROCZ, Johannes de: Chronica Hungarorum I. Textus, GALÁNTAI, Erzsébet - KRISTÓ, Gyula (eds.), Budapest 1985.

THUROCZ, Johannes de: Chronica Hungarorum II. Commentarii 2. Ab anno 1301 usque ad annum 1487, MÁLYUSZ, Elemér - KRISTÓ, Gyula (eds.), Budapest 1988. 